\title{
PENGARUH KOMUNIKASI ANTAR PERSONAL GURU TERHADAP PENCEGAHAN PRILAKU SEKS BEBAS SISWA PAB 8 SAINTIS TAHUN 2016
}

\author{
Joko Susanto, M.I.Kom \\ Program Studi Komunikasi dan Penyiaran Islam STAI As-Sunnah Deli Serdang \\ Jl. Medan-Tg. Morawa, km. 13, Gg. Darmo, Bangun Sari, Tg. Morawa, Deli Serdang, SUMUT \\ jokodhie@gmail.com
}

\begin{abstract}
Abstrak : Komunikasi antar personal merupakan bentuk komunikasi yang sangat sering terjadi dalam kehidupan manusia, dalam hal ini komunikasi antar personal guru dengan siswa merupakan sisi penting dalam lingkungan pendidikan untuk menanamkan nilai moralitas, ilmu pengetahuan, dan budaya sehingga komunikasi ini akan sangat mempengaruhi sikap dan perilaku khususnya pada siswa. Fenomena perilaku seks bebas dikalangan siswa belakangan ini telah menjadi perhatian banyak pihak khususnya bagi siswa menengah atas. Kasus putus sekolah dan pernikahan dini marak terjadi di lingkungan sekolah yang di latarbelakangi oleh perilaku seks bebas yang dilakukan siswa, ini juga tampak terjadi pada siswa SMA PAB 8 Saintis.

Penelitian ini dilakukan dengan tujuan untuk mengetahui seberapa besar pengaruh komunikasi antar personal guru terhadap pencegahan prilaku seks bebas siswa PAB 8 Saintis Tahun 2016. Hipotesa yang diangkat dalam penelitian ini adalah Terdapat pengaruh komunikasi antar personal guru terhadap pencegahan prilaku seks bebas siswa PAB 8 Saintis Tahun 2016.

Penelitian ini dilakukan di SMA Swasta PAB 8 Saintis. Penelitian ini dilakukan dengan pendekatan metode korelasional, dengan populasi seluruh siswa kelas IX yang berjumlah 104 orang dan diambil sampel sebanyak 40 siswa berdasarkan rumus $\mathbf{N}=\mathbf{N} / \mathbf{N} . d 2+1$. $(\mathrm{n}=$ Jumlah sampel. $\mathbf{N}=$ Jumlah populasi.d $2=$ Presisi yang ditetapka $10 \%$ dengan tingkat kepercayaan sebesar $90 \%$ ).

Dari hasil penelitian yang dilakukan menunjukkan bahwa komunikasi antar personal guru dengan siswa memberikan pengaruh terhadap pencegahan perilaku seks bebas siswa sebesar 23,6 \% sedangkan sisanya dipengaruhi variable lain.Secara keseluruhan dapat ditarik kesimpulan bahwa hasil penelitian ini membuktikan terdapat hubungan anatara komunikasi personal guru dengan siswa dalam mencegah perilaku seks bebas siswa di SMA PAB 8 Saeintis. Jika komunikasi guru tersebut ditingkatkan maka akan berpengaruh positif terhadap siswa, sehingga perilaku menyimpang tersebut semakin dapat ditekan dan turun. Faktor lain yang mungkin mempengaruhi perilaku seks bebas siswa antara lain keluraga, teman bermain, pendidikan agama dan lain sebagainya yang masih membutuhkan penelitian selanjutnya.
\end{abstract}

Kata Kunci : Komunikasi Antar Personal Guru, Perilaku seks Bebas Siswa. 


\section{Pendahuluan}

Komunikasi antar personal antara guru dan murid sering kali terabaikan dalam dunia pendidikan dewasa ini. Model komunikasi yang sering terjadi dalam kegiatan pendidikan di sekolah adalah komunikasi linier yang kaku, dalam hal ini sering kali guru memposisikan dirinya sebagai sosok yang penuh wibawa, harus dihormati dan bahkan ditakuti dihadapan siswa-siswanya. Hal ini yang kemudian sangat sulit membangun kedekatan emosional antara guru dan siswa tidak terbangun secara alami di lingkungan sekolah. Sehingga sering kali nasehatnasehat yang diberikan guru kepada siswa tentang berbagai hal termasuk perilaku seks bebas berlalu begitu saja, tanpa ada dorongan atau tanggung jawab siswa untuk melakukan nasehat tersebut.

Perilaku seks bebas pra nikah di kalangan remaja yang marak terjadi belakangan ini tidak terlepas dari pengaruh era globalisasi yang dianggap sebagai bentuk modernitas bagi sebagian remaja. Perkembangan tehnologi saat ini telah memberikan kemudahan bagi semua orang untuk mendapatkan informasi termasuk tentang seks. Kemudahan dalam mengakses informasi tentang seks tidak dijadikan sebagai sarana pendidikan dan pemahaman yang baik tentang perilaku seks, melainkan lebih berimplikasi negatif yang mengarah pada terjadinya perilaku seks bebas pranikah di kalangan remaja.

Perilaku seks bebas pranikah yang dilakukan pelajar merupakan suatu perbuatan yang tidak etis menurut budaya kita di Indonesia, perbuatan ini secara psikologi remaja mengakibatkan rasa bersalah dan penyesalan karena melanggar norma, depresi, ketegangan mental dan kebingungan untuk menghadapi segala kemungkinan resiko yang akan terjadi. Masalah lain yang kemudian akan muncul adalah terjadinya kehamilan diusia remaja, pengguguran kandungan (aborsi), putus sekolah, perkawinan di usia muda, perceraian, penyakit kelamin, HIV/AIDS, penyalahgunaan obat merupakan akibat buruk dari petualangan cinta dan seks yang salah pada saat remaja masih sebagai seorang pelajar. Akibatnya, masa depan mereka yang penuh dengan harapan menjadi hancur berantakan.

Perilaku seksual bebas pra nikah yang terjadi dikalangan remaja (pelajar) akhir-akhir ini cukup memprihatinkan. Beberapa penelitian yang dilakukan 
menunujukkan bahwa banyak para remaja pernah dan bahkan terbiasa melakukan hubungan seks bebas pranikah dengan pacarnya atas dasar saling suka dan untuk pemenuhan kebutuhan seksualitasnya atau untuk alasan tuntutan kebutuhan ekonomi. Sehingga banyak dari mereka yang sudah kehilangan keperawanan saat masih duduk di bangku sekolah.

Perilaku seks merupakan naluri alamiah setiap manusia, berkembangnya fisik dan psikis seseorang akan juga ikuti dengan hal-hal lainnya termasuk perilaku seks. Masa remaja merupakan masa yang sangat rentan terhadap perilaku negatif terutama hubungannya dengan penyimpangan seksualitas seperti seks bebas pranikah ini, kondisi tersebut tentunya banyak dipengaruhi oleh faktor internal dan eksternal remaja. Faktor lemahnya kontrol orang tua, guru di sekolah dan kurangnya pendidikan agama serta lingkungan remaja yang negatif dan mendukung prilaku seks menyimpang tersebut. Selain itu, faktor internal penyebab terjadinya perilaku seks pranikah yaitu lemahnya konsep diri remaja yang disebabkan oleh lemahnya iman dan pemahaman agama yang baik pada diri remaja.

Telah banyak penelitian yang dilakukan berhubungan dengan perilaku seks bebas pranikah dikalangan pelajar, secara umum hasil penelitian tersebut menunjukkan bahwa perilaku seks bebas pranikah menunjukkan peningkatan setiap tahunnya. Seperti penelitian yang dilakukan oleh Dini Susanti, mahasiswa psikologi UIIS Malang tahun 2002, yang memaparkan bahwa 50\% dari responden menyatakan bahwa hubungan seks pranikah adalah suatu hal yang wajar dan mereka tidak mampu mengontrol diri untuk tidak melakukan seks pranikah karena mereka didukung oleh pergaulan ${ }^{1}$.

Kasus mengenai perilaku seksual pada remaja dari waktu ke waktu semakin mengkhawatirkan termasuk di kalangan pelajar tingkat SMA sederajat. Dari mulai berpegangan tangan, berciuman bibir, berpelukan dan bahkan melakukan hubungan intim layaknya suami istri sering kita dengar di tengahtengah kita dan sudah bukan rahasia lagi bahwa telah banyak pelajar yang sudah

${ }^{1}$ Dini Susanti, Kontrol Diri dalam Perilaku Seks Pranikah Mahasiswa UIIS Malang. Skripsi (tidakditerbitkan), ( Malang: UIIS Malang, 2002). 
tidak perawan lagi disebabkan perilaku seks bebas yang mereka lakukan. Sebagai contoh, beredarnya video porno (mesum) yang dilakukan oleh sepasang pelajar menengah atas melaui handphone. Selanjutnya, banyaknya film porno yang berdurasi singkat tersimpan di banyak handphone pelajar SMP dan SMA.

Tidak jarang kasus putus sekolah terjadi di beberapa sekolah menengah atas di Kecamatan Percut Sei Tuan dikarena telah terjadi kehamilan diluar nikah yang di dasarkan pada terlalu bebasnya pergaulan seks yang mereka lakukan. Selain itu, kasus aborsi juga sering terjadi yang dilakukan oleh siswa-siswa SMA Swasta di Kecamatan Percut Sei Tuan, dan mungkin masih banyak lagi kasuskasus yang terjadi dikarena perilaku seks bebas yang dilakukan siswa SMA di Kecamatan Percut Sei Tuan yang luput dari pandangan masyarakat.

Fenomena ini menjadi perhatian serius peneliti untuk mengungkap sebuah fakta tentang komunikasi guru dengan siswa dalam mencegah perilaku seks bebas pranikah yang terjadi di tengah-tengah pelajar SMA, khusunya di daerah pinggiran kota. Dalam penelitian ini, peneliti mengambil lokasi penelitian di SMA Swasta PAB 8 Saintis, dengan mengangkat judul penelitian yaitu: Pengaruh Komunikasi Antar personal Guru Terhadap Pencegahan Perilaku Seks Bebas Siswa Di SMA PAB 8 Saintis.

\section{Pembahasan}

1. Komunikasi Antar Personal

Komunikasi antar personal, atau selalu juga disebut dengan komunikasi antar pribadi merupakan bagian dari komunikasi secara umum. Muhammad mengemukakan pandangannya tentang komunikasi antar personal yaitu: "Komunikasi antar personal adalah proses pertukaran informasi di antara seseorang dengan paling kurang seseorang lainnya atau biasanya di antara dua orang yang dapat langsung diketahui balikannya". ${ }^{2}$

Menurut Permana yang dikutip oleh Purwanto komunikasi antar personal adalah: suatu proses penyampaian pesan dari seseorang kepada orang lain/pihak lain. Menurut pemahaman seperti ini, komunikasi dikaitkan dengan pertukaran

\footnotetext{
${ }^{2}$ Muhammad, Komunikasi Organisasi, (Jakarta: Bumi Aksara, 2002), h. 159.
} 
informasi yang bermakna dan harus membawa hasil diantara orang-orang yang berkomunikasi. Komunikasi antar personal menghendaki informasi atau pesan dapat tersampaikan dan hubungan di antara orang yang berkomunikasi dapat terjalin. $^{3}$

Berdasarkan pemahaman di atas, dapat disimpulkan bahwa komunikasi antar personal merupakan komunikasi yang dijalin oleh pihak perorangan dengan pihak lain sehingga terjadi suatu proses interaksi hubungan dan penyampaian informasi atau pesan yang dapat dipahami oleh kedua belah pihak, sehingga menimbulkan respon berupa tingkah laku yang diharapkan. Selanjutnya, menurut Hardjana Komunikasi antar personal mempunyai ciri-ciri sebagai berikut:

a. Komunikasi Antar personal adalah verbal dan non-verbal

b. Komunikasi Antar personal mencakup perilaku tertentu (Perilaku spontan, perilaku menurut kebiasaan, perilaku sadar).

c. Komunikasi antar personal adalah komunikasi yang berproses pengembangan. Komunikasi antar personal berkembang berawal dari saling pengenalan yang dangkal, berlanjut makin mendalam, dan berakhir dengan saling pengenalan yang amat mendalam.

d. Komunikasi antar personal mengandung umpan balik, interaksi, dan koherensi. Supaya komunikasi antar personal berjalan teratur, pihak-pihak yang terlibat saling menanggapi sesuai pesan yang diterima. Dari sini terjadi koherensi dan umpan balik yang diberikan.

e. Komunikasi antar personal berjalan menurut peraturan tertentu. Komunikasi antar personal hendaknya mengikuti peraturan yang berlaku secara intrinsik dan ekstrinsik.

f. Komunikasi antar personal adalah kegiatan aktif. Komunikasi antar personal bukan sekedar komunikasi dari pengirim kepada penerima pesan dan sebaliknya, tetapi serangkaian proses saling penerimaan, penyerapan, dan penyampaian tanggapan yang sudah diolah oleh masing-masing pihak.

3 Purwanto, Pengaruh Komunikasi Antar personal Kepala Sekolah Terhadap Iklim KerjaGuru, (Bandung: Skripsi UPI, 2004), h. 15. 
g. Komunikasi antar personal saling mengubah. Komunikasi antar personal merupakan wadah atau sarana saling belajar dan mengembangkan wawasan, pengetahuan, dan kepribadian. ${ }^{4}$

Selanjutnya, Thoha ${ }^{5}$ mengemukakan mengemukakan bahwa komunikasi antar personal dapat dikatakan efektif bila adanya beberapa unsur berikut:

a. Keterbukaan

Keterbukaan, amat besar pengaruhnya dalam menumbuhkan komunikasi antar personal yang efektif. Untuk menunjukkan kualitas keterbukaan dari komunikasi antarpribadi ini paling sedikit ada dua aspek, yakni aspek keinginan untuk terbuka bagi setiap orang yang berinteraksi dengan orang lain dan keinginan untuk menanggapi secara jujur stimulus yang datang kepadanya. Keinginan terbuka dimaksudkan agar diri masing-masing tidak tertutup di dalam menerima informasi dan berkeinginan untuk menyampaikan informasi dari dirinya bahkan juga informasi mengenai dirinya apabila dipandang relevan dalam rangka pembicaraan antarpribadi dengan lawan bicaranya. Sedangkan keinginan untuk menanggapi secara jujur semua stimuli yang datang kepadanya dapat dengan sikap apa saja dan apa adanya. Diam, tidak bereaksi, tidak mau mengkritik, atau bahkan tidak mau bergerak secara fisik barangkali mungkin tepat untuk suatu situasi tertentu, tetapi dalam komunikasi antarpribadi atau dalam percakapan sehari-hari akan membosankan. Dalam keterbukaan ini sudah sewajarnya apabila masing-masing mau bereaksi secara terbuka terhadap apa yang dikatakan oleh masing-masing orang. Tidak ada yang paling buruk kecuali ketidakpedulian (indifference), dan tidak ada yang paling menyenangkan selain penghargaan atas perbedaan pendapat.

\section{b. Empathy}

Empathy, ialah kemampuan seseorang untuk memproyeksikan dirinya kepada peranan orang lain. Apabila komunikator atau komunikan atau keduaduanya mempunyai kemampuan untuk melakukan empati dengan orang lain, kemungkinan besar akan terdapat komunikasi yang efektif. Jika seorang

\footnotetext{
${ }^{4}$ Hardjana, Komunikasi Intrapersonal dan Antar personal, (Yogyakarta: Kanisisus, 2003), h. 86-90.

${ }^{5}$ Thoha, Perilaku Organisasi, (Jakarta: Rajawali Pers, 1996), h. 166.
} 
komunikator mempunyai empati yang dalam dengan komunikan, maka komunikator dan komunikan mampu menciptakan suasana komunikasi yang efektif. Dengan empati, mereka dimaksudkan untuk dapat merasakan sebagaimana yang dirasakan oleh orang lain, satu dengan lainnya. Jika dalam komunikasi dengan kerangka empati, maka seseorang akan memahami posisinya, darimana mereka berasal, dimana mereka sekarang, dan kemana mereka akan pergi. Dan yang paling penting adalah kita tidak akan memberikan penilaian pada perilaku atau sikap mereka sebagai perilaku atau sikap yang salah atau benar. Sedangkan simpati merasakan untuk orang lain, misalnya merasa kasihan pada orang lain.

\section{c. Dukungan}

Dukungan, adakalanya terucapkan dan adakalanya tidak terucapkan. Dukungan yang tidak terucapkan tidaklah mempunyai nilai yang negatif melainkan dapat merupakan aspek yang positif dari komunikasi. Gerakan-gerakan seperti anggukan kepala, kerdipan mata, senyum atau tepukan tangan, merupakan dukungan positif yang tak terucapkan. Jika partisipan dalam suatu komunikasi merasa bahwa apa yang dikatakan akan mendapat kritikan, atau diserang, maka mereka akan segan untuk berlaku terbuka atau enggan memberitahukan tentang dirinya dalam cara apapun.

\section{d. Kepositifan}

Kepositifan, terdapat tiga hal yang perlu diuraikan. Pertama, komunikasi antarpribadi akan berhasil jika terdapat perhatian yang positif terhadap diri seseorang. Apabila beberapa orang mempunyai perasaan negatif terhadap dirinya, mereka akan mengomunikasikan perasaan tersebut kepada orang lain, maka orang lain ini kemungkinan akan mengembangkan rasa negatif pula. Sebaliknya, apabila orang-orang mempunyai perasaan positif terhadap dirinya berkeinginan akan menyampaikan perasaannya kepada orang lain tersebut akan menanggapi dan memperhatikan perasaan positif tadi. Kedua, komunikasi antar pribadi akan terpelihara dengan baik jikalau suatu perasaan yang positif terhadap orang lain itu dikomunikasikan. Hal ini akan membuat orang lain tersebut merasa lebih baik dan mempunyai keberanian untuk lebih berpartisipasi pada setiap kesempatan. Ketiga, 
suatu perasaan positif dalam situasi komunikasi umum, amat bermanfaat untuk mengefektifkan kerja sama. Hal yang paling tidak menyenangkan apabila berkomunikasi dengan orang lain yang tidak tertarik atau tidak memberikan respon yang menyenangkan terhadap situasi yang dibicarakan.

\section{e. Kesamaan}

Kesamaan, merupakan karakteristik yang istimewa. Pada kenyataannya manusia tidak ada yang sama. Jika antara komunikator dan komunikan terdapat persamaan dalam pengertian, sikap, dan bahasa, komunikasi di antara mereka itu akan lebih efektif. Kebanyakan orang menyenangi interaksi dengan orang-orang yang benar-benar sama dalam status sosial, pendidikan, kepercayaan, dan sebagainya. Ini bukan berarti bahwa orang-orang yang tidak mempunyai kesamaan tidak bisa berkomunikasi. Akan tetapi, bila mereka menginginkan komunikasi yang efektif, mereka perlu mengetahui kesamaan-kesamaan kepribadian di antara mereka. Dengan cara ini, dimaksudkan agar kedua pihak yang berkomunikasi dihargai dan dihormati sebagai manusia yang memiliki kontribusi terhadap sesamanya. Karakteristik kesamaan dalam komunikasi antarpribadi dapat pula dilihat dari kedudukan antara komunikator dan komunikan.

\section{Perilaku Seks Remaja}

Seks dalam arti sempit diartikan kelamin, anggota-anggota tubuh dan ciriciri badaniah lainnya yang membedakan laki-laki dan wanita, kelenjar-kelenjar dan hormon yang mempengaruhi alat kelamin, hubungan kelamin dan proses pembuahan, kehamilan dan kelahiran. Sedangkan seks dalam arti luas yaitu segala hal yang terjadi sebagai akibat (konsekuensi) dari adanya jenis kelamin, seperti perbedaan tingkah laku, perbedaan atribut (pakaian, nama), perbedaan peran dan pekerjaan serta hubungan antara pria dan wanita (tata krama pergaulan, etika dan lain-lain). Oleh karena itu, sebagai usaha pendidikan, komunikasi tentang seks yang dilakukan orang tua dengan anak tidak boleh terlepas dari segi seksualitas yang luas tersebut. ${ }^{6}$

${ }^{6}$ Sarwono, Sarlito. W \& Ami Siamsidar, Peranan Orang Tua dalam Pendidikan Seks, (Jakarta: CV Rajawali, 1986), h, 7-8. 
Istilah seks lebih tepat untuk menunjukkan alat kelamin. Namun, seringkali masyarakat umum (awam) memiliki pengertian bahwa istilah seks lebih mengarah pada bagaimana masalah hubungan seksual antara dua orang yang berlainan jenis kelamin. Adapun pengetahuan tentang masalah seksualitas, berkaitan dengan anatomi seksual (organ-organ tubuh), fungsi hormon seksual, dan perilaku seksual dalam kehidupan sosial.

Perilaku seks adalah segala tingkah laku yang didorong oleh hasrat seksual, baik dengan lawan jenis maupun sesama jenis. Bentuk-bentuk tingkah laku ini dapat bermacam-macam, mulai dari perasaan tertarik sampai tingkah laku berkencan, bercumbu dan bersenggama. Obyek seksualnya dapat berupa orang lain, orang dalam khayalan ataupun dari diri sendiri. ${ }^{7}$

Berdasarkan pengertian di atas dapat disimpulkan bahwa perilaku seks pranikah adalah suatu aktivitas seksual yang didorong oleh hasrat seksual, yang dilakukan oleh pria dan wanita sebelum adanya ikatan resmi (pernikahan) menurut agama dan hukum, mulai dari bentuk perilaku seks yang paling ringan sampai tahapan senggama.

Perilaku negatif remaja terutama hubungannya dengan penyimpangan seksualitas seperti seks pranikah ini, dipengaruhi oleh faktor-faktor internal (dari diri remaja sendiri) serta faktor eksternal (berasal dari luar) yang mendukung perilaku tersebut.

Faktor-faktor internal yang menyebabkan terjadinya perilaku seks pranikah antara lain:

a. Meningkatnya libido seksualitas, dimana menurut Freud bahwa energienergi seksual berkaitan erat dengan kematangan fisik.

b. Proses kematangan organ tubuh yang menyangkut perkembangan fisik maupun kematangan organ-organ seksual dikendalikan oleh kelenjar endokrin yang terletak pada dasar otak. Kelenjar pituari ini menghasilkan dua hormon, yaitu hormon pertumbuhan yang mempengaruhi ukuran dan bentuk fisik tubuh individu, dan hormon gonadotropik yang merangsang kelenjar gonad (kelenjar seks) menjadi lebih aktif sehingga menimbulkan

\footnotetext{
${ }^{7}$ Sarwono, Psikologi Remaja, (Jakarta: Rajawali Press, 1991), h. 137
} 
rangsangan-rangsangan seksual.

c. Kualitas diri pribadi seperti kurangnya kontrol diri atau pengendalian diri, motivasi kesenangan, pengalaman emosional yang kurang sehat, terhambatnya perkembangan hati nurani yang agamis, ketidakmampuan mempergunakan waktu luang dengan baik. ${ }^{8}$

Faktor-faktor eksternal yang menjadi penyebab terjadinya perilaku seks pranikah antara lain:

a. Kurangnya informasi tentang seks. Hubungan seks dianggap ekspresi rasa cinta. Selain itu tidak tersedianya informasi yang akurat dan benar tentang kesehatan reproduksi memaksa remaja mencari akses dan mengeksplorasi sendiri. Majalah, buku dan film pornografis yang memaparkan kenikmatan hubungan seks tanpa mengajarkan tanggung jawab yang harus disandang dan resiko yang harus dihadapi, menjadi acuan utama mereka.

b. Percintaan. Hubungan seks pada remaja umumnya akibat berpacaran atau percintaan dan beberapa di antaranya berorientasi pada pemuasan nafsu.

c. Kurangnya komunikasi yang terbuka antara orang tua dan anak sehingga memperkuat munculnya perilaku yang menyimpang.

d. Pergaulan. Menurut Hurlock, perilaku seksual sangat dipengaruhi oleh lingkungan pergaulannya, terutama pada masa pubertas dimana pengaruh teman sebaya lebih besar dibandingkan orang tua.

e. Adanya penundaan usia perkawinan yang menyebabkan tidak segera dilakukan penyaluran kebutuhan biologis yang tepat.

Menurut sebuah penelitian yang dilakukan oleh Yayasan Keluarga Besar Kaiser (Kaiser Family Foundation, dalam Santrock, 1998), faktor yang mendorong remaja melakukan hubungan seks pranikah adalah:

a. Hubungan seks: bentuk penyaluran kasih sayang yang salah dalam pacaran seperti ungkapan kasih sayang dengan pemberian hadiah bunga, berpelukan, berciuman dan bahkan melakukan hubungan seks.

b. Faktor religiusitas, kehidupan iman yang rapuh. Individu yang rapuh imannya cenderung mudah melakukan pelanggaran terhadap ajaran agama.

\footnotetext{
${ }^{8}$ Ibid.,. h 149.
} 
c. Faktor kematangan biologis, sehingga remaja sudah dapat melakukan fungsi reproduksi layaknya orang dewasa. Kematangan biologis yang tidak disertai dengan kemampuan mengendalikan diricenderung berakibat negatif seperti perilaku seks pranikah, sebaliknya kematangan biologis yang disertai dengan kemampuan mengendalikan diri akan membawa kebahagiaan bagi remaja di masa depannya ${ }^{9}$. Berdasarkan paparan di atas dapat disimpilkan bahwa faktor yang mempengaruhi remaja melakukan perilaku seks pranikah, diantaranya persepsi yang salah dalam mengartikan suatu perasaan dan hubungan dalam berpacaran, faktor religiusitas (keimanan), faktor kematangan biologis yang berkaitan dengan pengendalian diri, kontrol diri, media massa, pornografi serta rasa ingin tahu yang tinggi mengenai masalah seks.

\section{Metodelogi Penelitian}

Penelitian ini dilakukan di SMA Swasta PAB 8 Saintis, yang terletak di Desa Saintis Kecamatan Percut Sei Tuan Kab. Deli Serdang Provinsi Sumatera Utara. Pemilihan lokasi penelitian ini berdasarkan observasi awal tentang perilaku siswa di sekolah tersebut.

Penelitian ini adalah penelitian kuantitatif dengan pendekatan korelasional, yang ingin melihat hubungan antara variabel yang digunakan, maka metode yang paling tepat digunakan adalah metode korelasi. Karena hubungan yang dicari bukanlah hubungan kausal atau sebab akibat, maka metode penelitiannya adalah metode penelitian korelasional.

Populasi dalam penelitian ini adalah seluruh siswa kelas IX PAB yang berjumlah 104 orang. Berdasarkan populasi yang ada maka peneliti menetapkan jumlah sampel berdasarkan teori T. Yamane. Dengan rumus $\mathbf{N}=\mathbf{N} / \mathbf{N} . \mathbf{d} 2+\mathbf{1}$. (n $=$ Jumlah sampel. $\mathrm{N}=$ Jumlah populasi.d $2=$ Presisi yang ditetapka $10 \%$ dengan tingkat kepercayaan sebesar $90 \%$ ).

\footnotetext{
${ }^{9}$ Dariyo, Agoes, Perkembangan Remaja. (Bogor. PT. Ghalia Indonesia, 2004). h. 89-90.
} 
Dengan menggunakan rumus ini diperoleh sampel penelitian sebagai berikut :

$$
\begin{aligned}
\mathrm{n} & =104 / 104 .(0,1) 2+1 \\
& =104 / 104 .(0,01)+1 \\
& =104 / 2,55 \\
& =40,7 \text { maka } \mathrm{n}=40 \text { (digenapkan). }
\end{aligned}
$$

Ada pun proses untuk menentukan sampel 40 (empat puluh) orang siswa tersebut, penulis melakukan dengan sistem Teknik Random Sampling.Teknik random sampling adalah teknik pengambilan sampel dimana semua dalam populasi baik secara sendiri-sendiri atau bersama-sama diberi kesempatan yang sama untuk dipilih menjadi anggota sampel. ${ }^{10}$

Tehnik pengumpulan data yang digunakan penulis adalah menggunakan metode Ex post facto atau metode Kausal Komperatif. Yaitu suatu cara mengumpulkan data yang telah terjadi yang menimbulkan akibat terhadap masa sekarang ataupun masa yang akan datang. Dan antara sebab akibat itulah yang akan diteliti pengaruhnya.Metode Ex post factoini menyerupai metode experiment, tetapi bedanya metode Xe post facto peneliti tidak mengendalikan variable bebas, karena variable bebas dianggap suatu peristiwa yang sudah terjadi. Penyelidikan empiris yang sistematis dimana ilmuwan tidak mengendalikan variable bebas secara langsung karena perwujudan variable tersebut telah terjadi, atau karena variable bebas tersebut pada dasarnya memang tidak dapat di manipulasi. Intinya, hubungan di antara variable-variabel itu dilakukan tanpa intervensi langsung berdasarkan perbedaan yang mengiringi variable bebas dan variable terikat itu. ${ }^{11}$

Dari kutipan di atas peneliti tidak melakukan kegiatan memanipulasi variable terhadap subjek terhadap variable tetapi sekedar mengelompokkan subjek menurut variable yang berbeda. Dalam penelitian ini subjek akan dilihat dari adanya

\footnotetext{
${ }^{10}$ Narbuko,C., Achmadi, A,H. Metodologi Penelitian.(Jakarta : PT Bumi Aksara, 2004), h. 24.

${ }^{11}$ Ary Donald, dkk. Pengantar Penelitian Dalam Pendidikan, Alih Bahasa. Arief Furchon, (Surabaya, Usaha Nasional, 2002), h. 103.
} 
pengaruh komunikasi antar personal guru terhadap pencegahan preilaku seks bebas siswa.

Tehnik analisis data yang digunakan adalah teknik korelasi sederhana, dengan langkah-langkah sebagai berikut:

a. Pengujian Persyaratan analisis.

Analisis data dalam penelitian ini menggunakan statistik sebagai alat untuk menganalisis korelasi. Untuk dapat menggunakan analisis korelasi terdapat persyaratan yang harus dipenuhi diantaranya:

1. Uji normalitas untuk mengetahui apakah data berasal dari populasi yang berdistribusi normal. Uji normalitas ini menggunakan uji data chi kuadrat.

2. Uji linieritas untuk mengetahui apakah masing-masing data membentuk garis linier digunakan ANAVA Regresi.

Metode analisis kuantitatif menggunakan data statistik, dan kemudian terjadi kegiatan dalam analisis tersebut, antara lain yaitu mengelompokkan data berdasarkan variabel dan jenis responden, mentabulasi data berdasarkan variabel dan seluruh responden, menyajikan data tiap variabel yang diteliti, melakukan perhitungan untuk menjawab rumusan masalah dan melakukan perhitungan untuk menguji hipotesis. Setelah data terkumpul dari hasil penyebaran kuesioner, selanjutnya diolah, ditabulasi dan dianalisi menggunakan bantuan Microsoft Exel 2007 dan SPSS 24 for Windows.

\section{b. Pengujian Persyaratan Analisis}

- Uji Normalitas

Uji normalitas merupakan salah satu bagian dari uji persyaratan analisis data atau uji asumsi klasik, artinya sebelum kita melakukan analisis yang sesungguhnya, data penelitian tersebut kita lihat dulu apakah sebaran dari variabel-variabel penelitian sudah mengikuti distribusi kurva normal atau tidak dengan melakukan uji normalitas. Dasar pengambilan keputusan dalam uji normalitas yakni, jika nilai signifikasi lebih besar dari 0,05 maka data tersebut berdistribusi normal, sebaliknya jikanilai signifikasi $<0,05$ maka data tersebut 
tidak normal. Adapun uji normalitas yang digunakan ini adalah menggunakan kolmogorov-smirnov, uji normalitas ini dilakukan dengan bantuanprogram SPSS 24 for Window.

Dalam hal ini digunakan untuk menentukan apakah distribusi frekuensi pengamatan dari suatu variabel secara signifikan berbeda dari yang diharapkan atau distribusi frekuensi teoritis. Sehingga hipotesis statistiknya adalah distribusi frekuensi hasil pengamatan bersesuaian dengan distribusi frekuensi harapan (teoritis).

\begin{tabular}{|l|l|r|r|}
\hline \multicolumn{3}{|l|}{ One-Sample Kolmogorov-Smirnov Test } \\
\hline \multicolumn{2}{|l|}{} & Komukasi & Pencegahan \\
\hline N & Mean & 60,43 & 40 \\
\cline { 2 - 4 } & $\begin{array}{l}\text { Std. } \\
\text { Normal Parameters }\end{array}$ & 55,15 \\
& Absiation & 7,659 & 7,127 \\
\hline Most Extreme & Absolute &, 207 &, 202 \\
\cline { 2 - 4 } Differences & Positive &, 161 &, 143 \\
\cline { 2 - 4 } & Negative &,- 207 &,- 202 \\
\hline Test Statistic &, 207 &, 202 \\
\hline Asymp. Sig. (2-tailed) &, $200^{c}$ &, $200^{c}$ \\
\hline a. Test distribution is Normal. & \\
\hline
\end{tabular}

Ho : Populasi berdistribusi normal

Ha : Populasi tidak berdistribusi normal

Dasar pengambilan keputusan adalah berdasarkan probabilitas

Jika nilai probabilitas $>0,05$ maka Ho diterima

Jikan nilai probabilitas $<=0,05$ maka Ho ditolak

Sehingga dari hasil Kolmogorov-Smirnov diatas maka

$\mathrm{X}=0,207$ yang artinya $>0,05$ maka populasi berdistribusi normal

$\mathrm{Y}=0,202$ yang artinya $>0,05$ maka populasi berdistribusi normal 


\section{- Uji Linearitas}

Uji linearitas bertujuan untuk mengetahui apakah dua variabel mempunyai hubungan yang linear atau tidak secara signifikan. Uji ini biasanya digunakan sebagai prasyarat dalam analisis korelasi atau regresi linear. Pengujian ini dapat menggunakan SPSS dengan memakai Test for Linearity pada taraf signifikansi 0,05. Dua variabel dikatakan mempunyai hubungan yang linear bila signifikansi (Deviation from Linearity) lebih dari 0,05.

\begin{tabular}{|c|c|c|c|c|c|c|c|}
\hline \multicolumn{8}{|c|}{ ANOVA Table } \\
\hline & & & $\begin{array}{l}\text { Sum of } \\
\text { Squares }\end{array}$ & df & $\begin{array}{l}\text { Mean } \\
\text { Square }\end{array}$ & $\mathrm{F}$ & Sig. \\
\hline \multirow{5}{*}{$\begin{array}{l}\text { Pencegahan } \\
* \\
\text { Komunikasi }\end{array}$} & \multirow[t]{3}{*}{$\begin{array}{l}\text { Between } \\
\text { Groups }\end{array}$} & $\begin{array}{l}\text { (Combined } \\
\text { ) }\end{array}$ & 929,800 & 16 & 58,113 & 1,271 & 293 \\
\hline & & Linearity & 467,741 & 1 & $\begin{array}{r}467,74 \\
1\end{array}$ & $\begin{array}{r}10,23 \\
3\end{array}$ & ,004 \\
\hline & & $\begin{array}{l}\text { Deviation } \\
\text { from } \\
\text { Linearity }\end{array}$ & 462,059 & 15 & 30,804 & ,674 & ,783 \\
\hline & \multicolumn{2}{|c|}{ Within Groups } & 1051,300 & 23 & 45,709 & & \\
\hline & \multicolumn{2}{|l|}{ Total } & 1981,100 & 39 & & & \\
\hline
\end{tabular}

Dari output di atas dapat diketahui bahwa nilai signifikansi (P Value Sig.) pada baris Deviation from Linearity sebesar 0,783. Karena signifikansi lebih dari 0,05 maka dapat disimpulkan bahwa antara (X) dan (Y) terdapat hubungan yang linear.

c. Pengujian Hipotesis

- Uji Korelasi

Korelasi merupakan teknik analisis yang termasuk dalam salah satu teknik pengukuran asosiasi / hubungan (measures of association). Pengukuran asosiasi merupakan istilah umum yang mengacu pada sekelompok teknik dalam statistik bivariat yang digunakan untuk mengukur kekuatan hubungan antara dua variabel. Diantara sekian banyak teknik-teknik pengukuran asosiasi, terdapat 
teknik korelasi yang sangat populer sampai sekarang, yaitu korelasi pearson product moment. Pengukuran asosiasi mengenakan nilai numerik untuk mengetahui tingkatan asosiasi atau kekuatan hubungan antara variabel. Dalam penelitian ini uji korelasi digunakan untuk melihat apakah terdapat hubungan antara variabel $\mathrm{X}$ (komunikasi antar personal guru) dengan variabel $\mathrm{Y}$ (pencegahan prilaku seks bebas siswa). Adapun hasilnya dapat dijabarkan sebagai berikut :

\begin{tabular}{|c|c|c|c|}
\hline \multicolumn{4}{|l|}{ Correlations } \\
\hline & & Komukasi & Pencegahan \\
\hline \multirow[t]{4}{*}{ Komunikasi } & Pearson & 1 &, $486^{* * *}$ \\
\hline & Correlation & & \\
\hline & Sig. (2-tailed) & & ,001 \\
\hline & $\mathrm{N}$ & 40 & 40 \\
\hline \multirow[t]{4}{*}{ Pencegahan } & Pearson & $486^{* * *}$ & 1 \\
\hline & Correlation & & \\
\hline & Sig. (2-tailed) & ,001 & \\
\hline & $\mathrm{N}$ & 40 & 40 \\
\hline
\end{tabular}

Dari output di atas diketahui, bahwa koefisien korelasi antara skala Komunikasi antar personal guru dan pencegahan prilaku seks bebas siswa adalah sebesar 0,486 dengan nilai signifikansi atau probabilitas $0.000(p>0.01)$. Berarti Ho ditolak dan Ha diterima. Hal ini menunjukkan ada pengaruh yang signifikan antara variable x dengan y. Artinya bahwa semakin positif tingkat variable x maka semakin baik pula variable y. Dari table di atas juga dapat dilihat bahwa nilai Pearson Correlation yang dihubungkan antara masing-masing variable mempunyai tanda bintang, ini berarti terdapat korelasi yang signifikan antara variable yang dihubungkan. 


\section{- Uji Regresi Sederhana}

Regresi Linear Sederhana adalah Metode Statistik yang berfungsi untuk menguji sejauh mana hubungan sebab akibat antara Variabel Faktor Penyebab (X) terhadap Variabel Akibatnya. Faktor Penyebab pada umumnya dilambangkan dengan $\mathrm{X}$ atau disebut juga dengan Predictor sedangkan Variabel Akibat dilambangkan dengan $\mathrm{Y}$ atau disebut juga dengan Response. Regresi Linear Sederhana atau sering disingkat dengan SLR (Simple Linear Regression) juga merupakan salah satu Metode Statistik yang dipergunakan dalam produksi untuk melakukan peramalan ataupun prediksi tentang karakteristik kualitas maupun kuantitas.Dalam penelitian ini uji regresi sederhana ini digunakan dengan tujuan untuk melihat besar hubungan antara variable $\mathrm{X}$ (komunikasi antar personal guru)denganvariabelY(pencegahan prilaku seks bebas siswa).Adapunhasilnya dapat dijabarkan sebagai berikut.

\begin{tabular}{|c|c|c|c|}
\hline \multicolumn{4}{|c|}{ Variables Entered/Removed $^{\mathrm{a}}$} \\
\hline Model & $\begin{array}{l}\text { Variables } \\
\text { Entered }\end{array}$ & $\begin{array}{l}\text { Variables } \\
\text { Removed }\end{array}$ & Method \\
\hline 1 & $\begin{array}{l}\text { Komunikasi } \\
\text { antar } \\
\text { personal } \\
\text { guru }^{\text {b }}\end{array}$ & & Enter \\
\hline \multicolumn{4}{|c|}{$\begin{array}{l}\text { a. Dependent Variable: Pencegahan prilaku seks } \\
\text { bebas siswa }\end{array}$} \\
\hline
\end{tabular}

Tabel ini menunjukkan menunjukkan variabel apa saja yang diproses, mana yang menjadi variabel bebas dan variabel terikat, yaitu komunikasi antar personal guru(x) sebagai variable bebas dan Pencegahan Prilaku seks bebas siswa (y) sebagai variable terikat. 


\begin{tabular}{|l|r|r|l|r|}
\hline \multicolumn{4}{|l|}{ Model Summary } \\
\hline Model & R & R Square & $\begin{array}{l}\text { Adjusted R } \\
\text { Square }\end{array}$ & $\begin{array}{l}\text { Std. Error of } \\
\text { the Estimate }\end{array}$ \\
\hline 1 &, $486^{\mathrm{a}}$ &, 236 &, 216 & 6,311 \\
\hline \multicolumn{7}{|r}{ a. Predictors: (Constant), Komunikasi antar personal guru } \\
\hline
\end{tabular}

Table ini menjelaskan besarnya nilai korelasi /hubungan (R) yaitu sebesar 0,486 nilai ini dapat diinterpretasikan bahwa hubungan kedua variabel penelitian ada di kategorikan sedang. Prosentase pengaruh variable bebas terhadap variable terikat yang disebut koefisien determinasi yang merupakan hasil dari peguadratan R. dari output tersebut diperoleh koefisien determinasi (R2) sebesar 0,236 yang mengandung pengertian bahwa variable bebas (Komunikasi antar personal guru) terhadap variable terikat (Pencegahan prilaku seks bebas siswa) adalah sebesar 23,6 \% sedangkan sisanya dipengaruhi variable lain.

\begin{tabular}{|c|c|c|c|c|c|c|}
\hline \multicolumn{7}{|c|}{ ANOVA $^{\mathrm{a}}$} \\
\hline \multicolumn{2}{|c|}{ Model } & $\begin{array}{l}\text { Sum of } \\
\text { Squares }\end{array}$ & Df & \begin{tabular}{|l} 
Mean \\
Square
\end{tabular} & $\mathrm{F}$ & Sig. \\
\hline \multirow[t]{3}{*}{1} & Regression & 467,741 & 1 & 467,741 & 11,745 &, $001^{\mathrm{b}}$ \\
\hline & Residual & 1513,359 & 38 & 39,825 & & \\
\hline & Total & 1981,100 & 39 & & & \\
\hline \multicolumn{7}{|c|}{ a. Dependent Variable: Pencegahan prilaku seks bebas siswa } \\
\hline \multicolumn{7}{|c|}{ b. Predictors: (Constant), Komunikasi antar personal guru } \\
\hline
\end{tabular}

Pada table ini menjelaskan apakah ada pengaruh yang nyata (signifikan) variable $\mathrm{x}$ terhadap variable $\mathrm{y}$. Dari output tersebut terlihat bahwa $\mathrm{F}$ hitung $=11$, 745 dengan tingkat signifikasi/probabilitas $0,000<0,05$, maka model regresi dapat dipakai untuk memprediksi variable Pencegahan prilaku seks bebas siswa. 


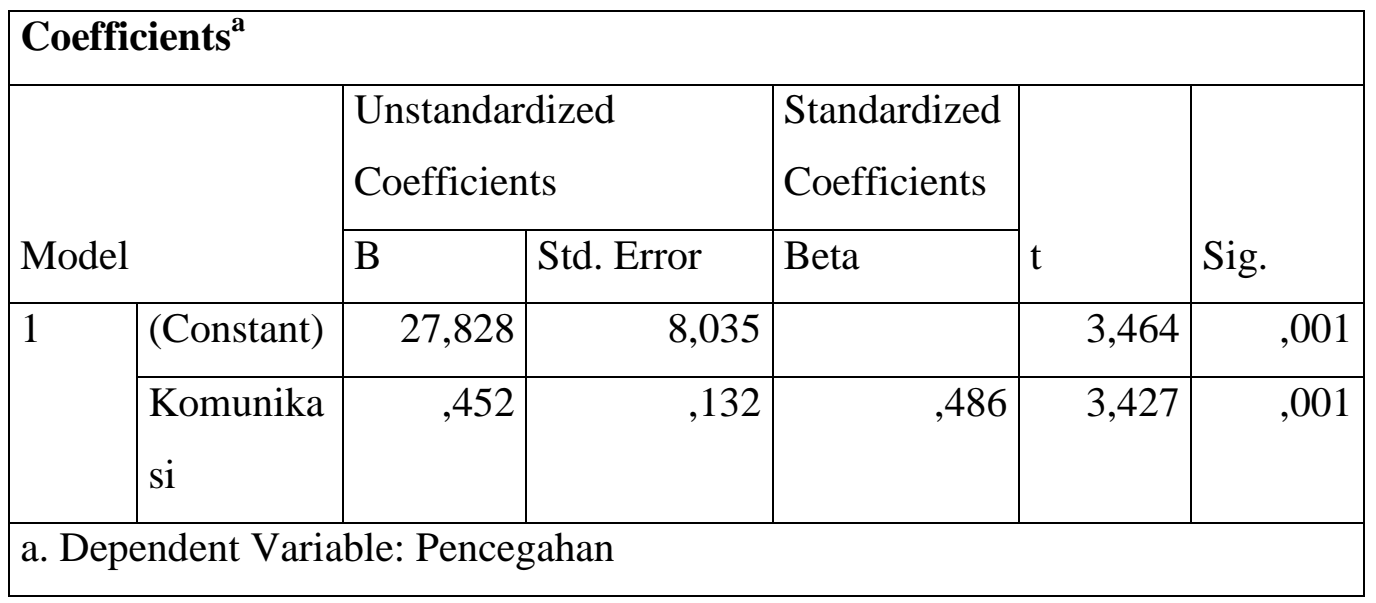

Pada table Coefficients, pada kolom B pada Constant (a) adalah 27,828, sedangkan nilai komunikasi antar personal (b) adalah 0,452, sehingga persamaan regresinya dapat ditulis :

\section{$\mathrm{Y}=\mathrm{a}+\mathrm{bX}$ atau $27,828+0,452 \mathrm{X}$}

Koefisient $\mathrm{b}$ dinamakan arah regresi dan menyatakan perubahan rata-rata variable $\mathrm{Y}$ untuk setiap perubahan variable $\mathrm{X}$ sebesar satu satuan. Perubahan ini merupakan pertambahan bila $\mathrm{b}$ bertanda positif dan penurunan bila $\mathrm{b}$ bertanda negative. Sehingga dari persamaan tersebut dapat diterjemahkan :

- Konstanta sebesar 27,828 menyatakan bahwa jika tidak ada nilai komunikasi antar personal guru maka nila pencegahan prilaku seks bebas siswa sebesar 27,828 .

- Koefisien regresi X sebesar 0,483 menyatakan bahwa setiap penambahan 1 nilai komunikasi antar personal guru, maka nilai pencegahan prilaku seks bebas siswa bertambah 0,483 .

Korelasi linear positif (+1)perubahan salah satu nilai variabel diikuti perubahan nilai variabel yang lainnya secara teratur dengan arah yang sama. Jika nilai variabel x mengalami kenaikan, maka variabel y akan ikut naik. Jika nilai variabel x mengalami penurunan, maka variabel y akan ikut turun. Apabila nilai koefisien korelasi mendekati +1 (positif satu) berarti pasangan data variabel $\mathrm{x}$ dan variabel y memiliki korelasi linear positif yang kuat/erat. 
Selain menggambarkan persamaan regresi output ini juga menampilkan uji signifikansi dengan uji t yaitu untuk menegtahui apakah ada pengaruh yang nyata (signifikan) variable $\mathrm{x}$ terhadap variable $\mathrm{y}$.

\section{Hipotesis}

- Ho : Tidak ada pengaruh yang nyata (signifikan) variable x terhadap variable $\mathrm{y}$

- H1 : Ada pengaruh yang nyata (signifikan) variable x terhadap variable y

Dari output di atas di ketahui nilai $\mathrm{t}$ hitung $=3,427$ dengan nilai signifikansi 0,001 < 0,05 maka Ho ditolak dan $\mathrm{H} 1$ diterima, yang berarti ada pengaruh yang nyata (signifikan) variable $\mathrm{x}$ terhadap variable $\mathrm{y}$.

\section{Hasil Penelitian dan Kesimpulan}

Berdasarkan uji korelasi dapat di ketahui bahwa koefisien korelasi antara skala Komunikasi antar personal guru dan pencegahan prilaku seks bebas siswa adalah sebesar 0,486 dengan nilai signifikansi atau probabilitas $0.000(p>0.01)$. Berarti Ho ditolak dan Ha diterima. Hal ini menunjukkan ada pengaruh yang signifikan antara variable $\mathrm{x}$ dengan $\mathrm{y}$. Artinya bahwa semakin positif tingkat variable x maka semakin baik pula variable y. Dari table dapat dilihat bahwa nilai Pearson Correlation yang dihubungkan antara masing-masing variable mempunyai tanda bintang, ini berarti terdapat korelasi yang signifikan antara variable yang dihubungkan.

Dari table summary menjelaskan besarnya nilai korelasi /hubungan (R) yaitu sebesar 0,486 nilai ini dapat diinterpretasikan bahwa hubungan kedua variabel penelitian ada di kategorikan sedang. Persentase pengaruh variable bebas terhadap variable terikat yang disebut koefisien determinasi yang merupakan hasil dari peguadratan R. dari output tersebut diperoleh koefisien determinasi (R2) sebesar 0,236 yang mengandung pengertian bahwa variable bebas (Komunikasi antar personal guru) terhadap variable terikat (Pencegahan prilaku seks bebas siswa) adalah sebesar 23,6 \% sedangkan sisanya dipengaruhi variable lain.

Pada table anova menjelaskan ada pengaruh yang nyata (signifikan) variable $\mathrm{x}$ terhadap variable $\mathrm{y}$. Dari output tersebut terlihat bahwa $\mathrm{F}$ hitung $=11$, 
745 dengan tingkat signifikasi/probabilitas $0,000<0,05$, maka model regresi dapat dipakai untuk memprediksi variable Pencegahan prilaku seks bebas siswa.

Secara keseluruhan dalam praktek komunikasi antar personal yang dijalankan oleh guru di sekolah PAB ini, terlihat telah sesuai dengan teori toha yang mengatakan bahwa komunikasi antar personal dapat dikatakan efektif bila adanya beberapa unsur berikut:

1. Keterbukaan

Keterbukaan, amat besar pengaruhnya dalam menumbuhkan komunikasi antar personal yang efektif. Untuk menunjukkan kualitas keterbukaan dari komunikasi antarpribadi ini paling sedikit ada dua aspek, yakni aspek keinginan untuk terbuka bagi setiap orang yang berinteraksi dengan orang lain dan keinginan untuk menanggapi secara jujur stimulus yang datang kepadanya. Keinginan terbuka dimaksudkan agar diri masing-masing tidak tertutup di dalam menerima informasi dan berkeinginan untuk menyampaikan informasi dari dirinya bahkan juga informasi mengenai dirinya apabila dipandang relevan dalam rangka pembicaraan antarpribadi dengan lawan bicaranya. Sedangkan keinginan untuk menanggapi secara jujur semua stimuli yang datang kepadanya dapat dengan sikap apa saja dan apa adanya. Diam, tidak bereaksi, tidak mau mengkritik, atau bahkan tidak mau bergerak secara fisik barangkali mungkin tepat untuk suatu situasi tertentu, tetapi dalam komunikasi antarpribadi atau dalam percakapan sehari-hari akan membosankan. Dalam keterbukaan ini sudah sewajarnya apabila masing-masing mau bereaksi secara terbuka terhadap apa yang dikatakan oleh masing-masing orang. Tidak ada yang paling buruk kecuali ketidakpedulian (indifference), dan tidak ada yang paling menyenangkan selain penghargaan atas perbedaan pendapat.

2. Empathy

Empathy, ialah kemampuan seseorang untuk memproyeksikan dirinya kepada peranan orang lain. Apabila komunikator atau komunikan atau keduaduanya mempunyai kemampuan untuk melakukan empati dengan orang lain, kemungkinan besar akan terdapat komunikasi yang efektif. Jika seorang komunikator mempunyai empati yang dalam dengan komunikan, maka 
komunikator dan komunikan mampu menciptakan suasana komunikasi yang efektif. Dengan empati, mereka dimaksudkan untuk dapat merasakan sebagaimana yang dirasakan oleh orang lain, satu dengan lainnya. Jika dalam komunikasi dengan kerangka empati, maka seseorang akan memahami posisinya, darimana mereka berasal, dimana mereka sekarang, dan kemana mereka akan pergi. Dan yang paling penting adalah kita tidak akan memberikan penilaian pada perilaku atau sikap mereka sebagai perilaku atau sikap yang salah atau benar. Sedangkan simpati merasakan untuk orang lain, misalnya merasa kasihan pada orang lain.

3. Dukungan

Dukungan, adakalanya terucapkan dan adakalanya tidak terucapkan. Dukungan yang tidak terucapkan tidaklah mempunyai nilai yang negatif melainkan dapat merupakan aspek yang positif dari komunikasi. Gerakan-gerakan seperti anggukan kepala, kerdipan mata, senyum atau tepukan tangan, merupakan dukungan positif yang tak terucapkan. Jika partisipan dalam suatu komunikasi merasa bahwa apa yang dikatakan akan mendapat kritikan, atau diserang, maka mereka akan segan untuk berlaku terbuka atau enggan memberitahukan tentang dirinya dalam cara apapun.

4. Kepositifan

Kepositifan, terdapat tiga hal yang perlu diuraikan. Pertama, komunikasi antarpribadi akan berhasil jika terdapat perhatian yang positif terhadap diri seseorang. Apabila beberapa orang mempunyai perasaan negatif terhadap dirinya, mereka akan mengomunikasikan perasaan tersebut kepada orang lain, maka orang lain ini kemungkinan akan mengembangkan rasa negatif pula. Sebaliknya, apabila orang-orang mempunyai perasaan positif terhadap dirinya berkeinginan akan menyampaikan perasaannya kepada orang lain tersebut akan menanggapi dan memperhatikan perasaan positif tadi. Kedua, komunikasi antar pribadi akan terpelihara dengan baik jikalau suatu perasaan yang positif terhadap orang lain itu dikomunikasikan. Hal ini akan membuat orang lain tersebut merasa lebih baik dan mempunyai keberanian untuk lebih berpartisipasi pada setiap kesempatan. Ketiga, suatu perasaan positif dalam situasi komunikasi umum, amat bermanfaat untuk 
mengefektifkan kerja sama. Hal yang paling tidak menyenangkan apabila berkomunikasi dengan orang lain yang tidak tertarik atau tidak memberikan respon yang menyenangkan terhadap situasi yang dibicarakan.

\section{Kesamaan}

Kesamaan, merupakan karakteristik yang istimewa. Pada kenyataannya manusia tidak ada yang sama. Jika antara komunikator dan komunikan terdapat persamaan dalam pengertian, sikap, dan bahasa, komunikasi di antara mereka itu akan lebih efektif. Kebanyakan orang menyenangi interaksi dengan orang-orang yang benar-benar sama dalam status sosial, pendidikan, kepercayaan, dan sebagainya. Ini bukan berarti bahwa orang-orang yang tidak mempunyai kesamaan tidak bisa berkomunikasi. Akan tetapi, bila mereka menginginkan komunikasi yang efektif, mereka perlu mengetahui kesamaan-kesamaan kepribadian di antara mereka. Dengan cara ini, dimaksudkan agar kedua pihak yang berkomunikasi dihargai dan dihormati sebagai manusia yang memiliki kontribusi terhadap sesamanya. Karakteristik kesamaan dalam komunikasi antarpribadi dapat pula dilihat dari kedudukan antara komunikator dan komunikan.

Berdasarkan pemahaman di atas, dapat disimpulkan bahwa komunikasi antar personal merupakan komunikasi yang dijalin oleh pihak perorangan dengan pihak lain sehingga terjadi suatu proses interaksi hubungan dan penyampaian informasi atau pesan yang dapat dipahami oleh kedua belah pihak, sehingga menimbulkan respon berupa tingkah laku yang diharapkan.

Secara keseluruhan dapat ditarik kesimpulan bahwa hasil penelitian ini membuktikan Korelasi linear positif $(+1)$ yakniperubahan salah satu nilai variabel diikuti perubahan nilai variabel yang lainnya secara teratur dengan arah yang sama. Jika nilai variabel $\mathrm{x}$ mengalami kenaikan, maka variabel y akan ikut naik. Jika nilai variabel x mengalami penurunan, maka variabel y akan ikut turun. Apabila nilai koefisien korelasi mendekati +1 (positif satu) berarti pasangan data variabel $\mathrm{x}$ dan variabel y memiliki korelasi linear positif yang kuat/erat. 


\section{Pustaka Acuan}

Artkinson, Rita L., Pengantar Psikologi. Jakarta: Erlangga, 1983.

Ary Donald, dkk.2002. Pengantar Penelitian Dalam Pendidikan, Alih Bahasa. Arief Furchon, Usaha Nasional, Surabaya.

Arikunto, Suharsimi. Metodologi Penelitian. Rineka Cipta, Jakarta, 1994.

Azwar, Saifuddin. Reliabilitas dan Validitas. Yogyakarta: Pustaka Pelajar, 2006

Bungin, M. Burhan. Penelitian Kualitatif. Jakarta: Kencana Prenada, 2007.

Dariyo, Agoes. Perkembangan Remaja. Bogor. PT. Ghalia Indonesia, 2004.

Daryanto, Tiffany. 2009. Hubungan antara Religius dengan Perilaku Seks Pranikah padaMahasiswa Indekost di Malang. Skripsi (tidak diterbitkan). Malang: Universitas NegeriMalang, 2009.

Departemen Agama RI, Al-Quran Al-Karim dan Terjemahannya. Bandung: Gema Risalah Press, 1989.

Duncan, J.W. Organizational Behavior 2 nd. Boston: Houhton Mifflin Co, 1981.

Effendy. Onong Uchjana. Ilmu, Teori Dan Filsafat Komunikasi. Jakarta: Citra Aditya Bakti, 2003.

Hardjana. Komunikasi Intrapersonal dan Antar personal. Yogyakarta: Kanisisus, 2003.

Kriyantono. Teknik Praktis Riset Komunikasi. Jakarta: Kencana Prenada Media Group, 2006.

Kotler, P dan Amstrony,G. Prinsip-prinsip Pemasaran 3 rd ed. Jakarta: Erlangga, 1997.

Leavit, H. Psikologi Manajemen, Sebuah Pengantar bagi Individual dan Kelompok dalam Organisasi. Jakarta: Erlangga, 1986.

Liliweri. Komunikasi : Serba Ada Serba Makna. Jakarta: Kencana, 2011.

Moleong, Lexy. J. Metode Penelitian Kualitatif. Bandung: Remaja Rosdakarya 2000.

Muhammad. Komunikasi Organisasi. Jakarta: Bumi Aksara, 2002.

Najati, Muhammad Utsman. Psikologi dalam Tinjauan Hadits Nab. Jakarta: Mustaqiim, 2002. 
Narbuko,C., Achmadi, A,H. 2004 . Metodologi Penelitian. Jakarta : PT Bumi Aksara

Purwanto. Pengaruh Komunikasi Antar personal Kepala Sekolah Terhadap Iklim Kerja Guru. Bandung: Skripsi UPI, 2004.

S. Nasution. Metode Reseach. Ikrar Mandiri Abadi, Jakarta: 2007.

Sarwono, Sarlito, W. Psikologi Lingkungan. Jakarta: Grasindo, 1995.

Sarwono, Sarlito. W \& Ami Siamsidar, Peranan Orang Tua dalam Pendidikan Seks. Jakarta: CV Rajawali, 1986.

Schemerhon, John. R. Managing Organizational Behavior. New York: John Willey and Sons, 1985.

Schramm, Wilbur. The Process and Effect Of Mass Communication. Urbajuna: University Of Lilinois Pres, 1995.

Simanjuntak, B \& Pasaribu, L.I. Pengantar Psikologi Perkembangan. Bandung: Tarsito, 1986.

Singaribun, Masri dan Sofian Effendi. Metodologi Penelitian Survei. Jakarta: LP3ES, 2002.

Skinner, Carles. E. Educational Psychology. New Delhi: Frenthical, 1974.

Slameto. Evaluasi Pendidikan. Jakarta: Bumi Aksara, 1988.

Susanti, Dini. Kontrol Diri dalam Perilaku Seks Pranikah; Mahasiswa UIIS Malang. Skripsi(tidakditerbitkan). Malang: UIISMalang, 2002.

Susanto, Eko Harry. Komunikasi Politik Dan Otonomi Daerah. Jakarta: Mitra Wacana Media, 2009.

Surachmad, Winarno. Metodologi Penelitian. Yayasan Fakultas Psikologi UGM, Yogyakarta, 1994.

Sugiyono. Metode Penelitian. CV. Haji Mas Agung, Jakarta, 1999.

Toha, Raiftah. Prilaku Organisasi, Konsep Dasar dan Aplikasinya. Jakarta: Raja Grafindo Persada 1999.

Ulwan, Abdullah Nasih. Pendidikan Seks Untuk Anak Ala Nabi. Solo: Pustaka Iltizam, 2009.

Wiryanto. Pengantar Ilmu Komunikasi. Jakarta: Grasindo, 2004. 


\section{Kontributor}

Vol. II. No. 1 Januari-Juni 2017

Fakhrurrozi, Dosen Hadis Program Studi Pendidikan Bahasa Arab Sekolah Tinggi Agama Islam As-Sunnah Deli Serdang.

Abdul Hafizh, Dosen Program Studi Ahwal Syakhshiyah STAI Balaiselasa Pesisir Selatan, SUMBAR.

Indra, Alumnus Program Studi Hukum Islam, Program Pascasarjana Universitas Islam Negeri Sumatera Utara - Indonesia.

Irham Dongoran, Alumnus Program Studi Hukum Islam, Program Pascasarjana Universitas Islam Negeri Sumatera Utara - Indonesia.

Fahrur Rozi S, Dosen Program Studi Pendidikan Bahasa Arab Sekolah Tinggi Agama Islam As-Sunnah Deli Serdang.

Ahmad Zaky, Dosen Program Studi Pendidikan Bahasa Arab Sekolah Tinggi Agama Islam As-Sunnah Deli Serdang.

Tiy Kusmarrabbi Karo, Dosen Program Studi Pendidikan Bahasa Arab Sekolah Tinggi Agama Islam As-Sunnah Deli Serdang.

Ojak Manurung, Mahasiswa Program Doktoral Universitas Islam Negeri Sumatera Utara - Indonesia.

Sopian Sinaga, Dosen Program Studi Pendidikan Bahasa Arab Sekolah Tinggi Agama Islam As-Sunnah Deli Serdang.

Mursal Aziz, Dosen Sekolah Tinggi Ilmu Tarbiyah Al-Ittihadiyah Labuhan Batu Utara, Sumatera Utara.

Joko Susanto, Dosen Program Studi Komunikasi dan Penyiaran Islam Sekolah Tinggi Agama Islam As-Sunnah Deli Serdang. 


\section{UCAPAN TERIMA KASIH}

Dewan Redaksi menyampaikan terima kasih dan apresiasi kepada penyunting ahli dalam proses penerbitan WARAQAT Vol. II. No. 1 Januari-Juni 2017. Mereka adalah:

1. Adel Almatrodi (Al-Imam Muhammad Ibn Saud Islamic University).

2. Balazs Huszka (Universiti Malaysia Kelautan).

3. Irwan Syahputra (Universitas Islam Negeri Sumatera Utara).

4. Ja'far (Universitas Islam Negeri Sumatera Utara).

5. Zulheddi (Universitas Islam Negeri Sumatera Utara).

6. Dasman Yahya Ma'ali (Universitas Islam Negeri Sutan Syarif Kasim Riau).

7. Aprijon Efendi (Universitas Islam Negeri Sutan Syarif Kasim Riau).

8. Muhammad Arifin (Sekolah Tinggi Dirasat Islamiyah Imam Syafii Jember). 


\section{PEDOMAN PENULISAN ARTIKEL JURNAL WARAQAT (JURNAL ILMU-ILMU KEISLAMAN) SEKOLAH TINGGI AGAMA ISLAM AS-SUNNAH}

1. Karya ilmiah yang ditulis dalam bentuk:

a. Karya ilmiah hasil penelitian.

Sistematika penulisan:

- Judul

- Abstraksi dan disertai dengan kata kunci

- Pendahuluan

- Materi dan metode

- Hasil pembahasan

- Kesimpulan atau ringkasan

- Daftar pustaka

b. Karya ilmiah konseptual (non penelitian)

Sistematika penulisan:

- Judul

- Abstraksi dan disertai dengan kata kunci

- Pendahuluan

- Bagian inti atau permasalahan

- Kesimpulan atau ringkasan

- Daftar pustaka

2. Bahasa artikel bersifat ilmiah dapat disampaikan dengan menggunakan:

- Bahasa Indonesia

- Bahasa Arab

- Bahasa Inggris

3. Spesifikasi penulisan sebagai berikut:

- Ukuran kertas A4

- Ketikan 1,5 spasi

- Jenis font untuk artikel Bahasa Indonesia/Inggris: Times New Roman dengan size 12, dan untuk artikel/tulisan Bahasa Arab: Traditional Arabic dengan size 18.

- Jumlah halaman 13-25 halaman

- Sofware: Microsoft Word

\section{Alamat pengiriman artikel:}

Redaksi Jurnal WARAQAT

STAI As-Sunnah Deli Serdang

Jl. Medan-Tg. Morawa km 13, Gg. Darmo, Bangun Sari, Tg. Morawa, Deli Serdang.

Email : p3m.assunnah@gmail.com

HP : 085361752361 